\title{
Pengaruh pemberian kopi terhadap kualitas spermatozoa tikus wistar (Rattus norvegicus) yang terpapar stres
}

\author{
${ }^{1}$ Risnawati A. Haris \\ ${ }^{2}$ Lydia Tendean \\ ${ }^{2}$ Grace Turalaki
}

\author{
${ }^{1}$ Kandidat Skripsi Fakultas Kedokteran Universitas Sam Ratulangi Manado \\ ${ }^{2}$ Bagian/SMF Biologi Fakultas Kedokteran Universitas Sam Ratulangi Manado \\ Email: risnawatiabdharishusain@yahoo.com
}

\begin{abstract}
The coffee beans composed of the compound caffeine, palmitic acid, linoleic acid and acid stearic. The content of caffeine in coffee can improve spermatozoa motility that are not motile by inhibiting cyclic nucleotide phosphodiesterase and affects the intracellular levels of cyclic AMP. Spermatozoa quality can be affected by various factors such as stress. In nocturnal animals, dark periode becomes a signal to do activity by suprachiasmatic nucleus. The change in activity of the nocturnal animals from initial condition in the dark then exposed to light can leads to stress. This study was aimed to determine the effect of coffee on the spermatozoa quality of wistar rats which had been exposed to stress. This was an experimental analytical study with a post-test only control group design. The study was conducted for 50 days from September to November 2016. The sample consisted of 9 rats divided into three groups: a control group (P0) is given only exposure to stress in the form of light, the treatment group 1 (P1) is given exposure to stress in the light form and liquid coffee $1 \mathrm{ml} / \mathrm{kg}$ and the treatment group 2 (P2) is given exposure to stress in the light form and coffee extracts. The results showed that there were significant differences in the concentration and motility treatment group 1 (P1) to the control group $(\mathrm{P} 0)$ which is $\mathrm{p}<0.05$ and significant differences in sperm motility treatment group 2 (P2) to the control group (P0) which is $\mathrm{p}<0.05$. Conclusion: Coffee administration could improve the quality of spermatozoa of wistar rats exposed to stress.
\end{abstract}

Keywords: stress, coffee, quality of spermatozoa.

\begin{abstract}
Abstrak:. Biji kopi tersusun dari senyawa kafein, asam palmatik, asam linoleat dan asam stearik. Kandungan kafein yang terdapat didalam kopi mampu meningkatkan motilitas spermatozoa yang tidak motil dengan cara menghambat siklus nukleotida fosfodiesterase dan mempengaruhi level intraseluler dari siklus AMP. Kualitas spermatozoa juga dapat dipengaruhi oleh berbagai faktor lain seperti stres. Pada hewan nokturnal periode gelap menjadi sinyal untuk beraktiftas dilakukan oleh suprachiasmatic nucleus. Perubahan aktivitas pada hewan nokturnal dari kondisi awalnya ditempat yang gelap lalu diberikan paparan cahaya dapat menyebabkan terjadinya stres. Penelitian ini bertujuan untuk mengetahui pengaruh pemberian kopi terhadap kualitas spermatozoa tikus wistar yang terpapar stres. Jenis penelitian ialah eksperimental analitik dengan post-test only control group design. Penelitian dilakukan selama 50 hari dari bulan September November 2016. Sampel sebanyak 9 ekor tikus dibagi menjadi tiga kelompok yaitu : kelompok kontrol $\left(\mathrm{P}_{0}\right)$ hanya diberikan paparan stres berupa cahaya, kelompok perlakuan $1\left(\mathrm{P}_{1}\right)$ diberikan paparan stres berupa cahaya dan cairan kopi $1 \mathrm{~mL} / \mathrm{KgBb}$ dan kelompok perlakuan $2\left(\mathrm{P}_{2}\right)$ diberikan paparan stres berupa cahaya dan ekstrak kopi. Hasil penelitian menunjukkan adanya perbedaan yang signifikan pada konsentrasi dan motilitas spermatozoa kelompok perlakuan 1 $\left(\mathrm{P}_{1}\right)$ terhadap kelompok kontrol $\left(\mathrm{P}_{0}\right)$ yaitu $\mathrm{p}<0,05$ dan perbedaan yang signifikan pada motilitas spermatozoa kelompok perlakuan $2\left(\mathrm{P}_{2}\right)$ terhadap kelompok kontrol $\left(\mathrm{P}_{0}\right)$ yaitu $\mathrm{p}<0,05$.
\end{abstract} Simpulan: Pemberian kopi meningkatkan kualitas spermatozoa yang terpapar stres.

Kata kunci: stres, kopi, kualitas spermatozoa 
Biji kopi mengandung $10-15 \%$ minyak kopi yang tersusun dari senyawa kafein, asam palmatik, asam linoleat dan asam stearik. ${ }^{1}$ Kandungan kafein yang terdapat didalam kopi mampu meningkatkan motilitas spermatozoa yang tidak motil dengan cara menghambat siklus nukleotida fosfodiesterase dan mempengaruhi level intraseluler dari siklus AMP. ${ }^{2}$

Terdapat perbedaan pendapat mengenai pengaruh kopi terhadap kualitas spermatozoa, seperti penelitian yang dilakukan oleh Sobreiro et al menemukan keterkaitan pada konsumsi kopi dengan peningkatan motilitas spermatozoa. ${ }^{3}$ Namun penelitian lain yang dilakukan oleh Parazzini et al menemukan terjadinya penurunan kualitas spermatozoa pada mereka yang mengkonsumsi kopi. ${ }^{4}$ Penelitian yang dilakukan oleh Ramlau Hansen et al menemukan konsumsi kopi tidak berpengaruh terhadap kualitas spermatozoa. ${ }^{5}$

Kualitas spermatozoa juga dapat dipengaruhi oleh berbagai faktor seperti stres, pola hidup, dan berbagai perubahan endokrin. ${ }^{6}$ Penelitian yang dilakukan oleh Mailman School of Public Health and Rutgers School of Public Health Columbia University menyebutkan bahwa stres psikologis mempengaruhi konsentrasi, morfologi dan kemampuan sperma untuk membuahi sel telur. ${ }^{7}$ Penelitian sebelumnya yang dilakukan oleh Giblin et al menyebutkan bahwa stres mempunyai dampak negatif pada konsentrasi, motilitas dan mofologi spermatozoa. $^{8}$ Menurut Turner et al, secara umum fungsi normal testis dipengaruhi oleh dua faktor utama, yaitu faktor internal dalam hal ini suhu tubuh dan pengaturan oleh sistem hipotalamus-hipofisis. Dan faktor eksternal dalam hal ini faktor psikologi, masa pencahayaan, suhu lingkungan, nutrisi, bahan-bahan kimia tertentu dan hubungan sosial. $^{9}$

Pada kelompok hewan nokturnal, periode gelap menjadi sinyal untuk beraktifitas. Perubahan pada aktifitas hewan nokturnal yang diberikan paparan cahaya dapat menyebabkan terjadinya stres. Menurut
Wen - Pei et al, perubahan durasi cahaya (fotoperiode) tertentu diketahui turut pula menginduksi respon stres. ${ }^{10}$ Fungsi regulasi pada hewan nokturnal tersebut dilakukan oleh sepasang kumpulan saraf di hipotalamus yang dikenal sebagai suprachiasmatic nucleus (SCN). SCN menggunakan informasi cahaya (fotoperiode) untuk menyelaraskan proses faal internal tubuh dengan kondisi eksternal hewan. ${ }^{11,12}$

SCN mampu mengatur sekresi sejumlah hormon melalui hubungan saraf dengan neuron-neuron penghasil hormon pada hipotalamus. ${ }^{11}$ Regulasi hormonal yang turut dipengaruhi oleh SCN adalah hormon reproduksi melalui sumbu hormonal hipotalamus-hipofisis-gonad (HPG) dan hormon stres melalui sumbu hormonal hipotalamus-hipofisis-adrenal (HPA). ${ }^{12,13}$

Berdasarkan latar belakang yang diuraikan di atas, didapatkan adanya perbedaan pendapat pada penggunaan kopi dalam mempengaruhi kualitas spermatozoa serta pengaruh stres melalui papran cahaya terhadap kualitas spermatozoa. Oleh karena itu peneliti tertarik untuk melakukan penelitian mengenai pengaruh kopi terhadap kualitas spermatozoa tikus wistar (Rattus norvegicus) yang terpapar stres.

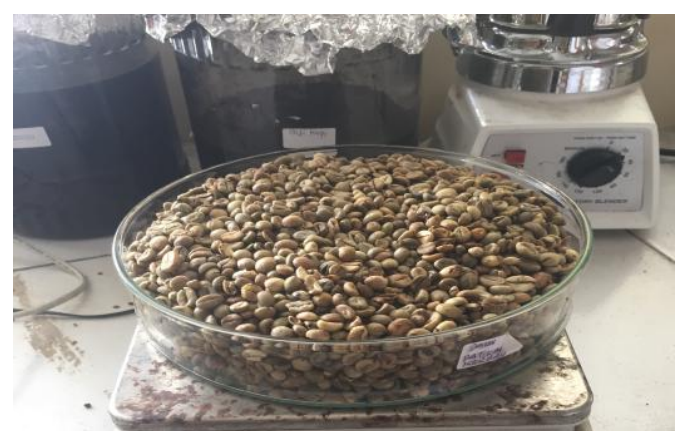

Gambar 1. Biji kopi robusta

\section{METODE PENELITIAN}

Desain penelitian yang digunakan adalah penelitian eksperimental analitik dengan pendekatan post-test only control group design. Penelitian dilakukan pada bulan September 2016 - November 2016. Penelitian dilaksanakan di Bagian Biologi 
Fakultas Kedokteran Kleak Universitas Sam Ratulangi Manado. Populasi penelitian ini adalah tikus wistar jantan (Rattus norvegicus). Sampel penelitian ini adalah 9 ekor tikus wistar jantan (Rattus norvegicus) yang telah memenuhi kriteria Inklusi. Kelompok sampel dibagi menjadi 3 kelompok, yaitu : Kelompok kontrol hanya di berikan paparan stres berupa cahaya, kelompok perlakuan 1 diberikan paparan stres berupa cahaya dan cairan kopi 1 $\mathrm{mL} / \mathrm{KgBb}$, kelompok perlakuan 2 diberikan paparan stres berupa cahaya dan ekstrak kopi. Data hasil pemeriksaan dianalisis dengan program pengolahan data di komputer.

\section{HASIL PENELITIAN \\ Konsentrasi Spermatozoa}

Pada Tabel 1 dapat dilihat bahwa terdapat peningkatan rerata konsentrasi pada kelompok sampel perlakuan 1 dengan pemberian paparan stres dan cairan kopi 1 $\mathrm{mL} / \mathrm{KgBb}$.

Tabel 1. Hasil Perhitungan Rerata Konsentrasi Spermatozoa Tikus Wistar (Rattus norvegicus) setelah perlakuan stres dan pemberian kopi selama 50 hari.

\begin{tabular}{ll}
\hline $\begin{array}{l}\text { Kelompok } \\
\text { sampel }\end{array}$ & $\begin{array}{l}\text { Konsentrasi } \\
\text { Spermatozoa } \\
\left(\mathbf{1 0}^{\mathbf{6}} \text { per } \mathbf{~ m L}\right)\end{array}$ \\
\hline Kontrol (P0) & 32.5 \\
Perlakuan (P1) & 48 \\
Perlakuan (P2) & 14.4 \\
\hline
\end{tabular}

\section{Motilitas Spermatozoa}

Motilitas spermatozoa tikus wistar (Rattus norvegicus) pada masing-masing kelompok terbagi menjadi 2 kategori, yaitu: rerata motilitas spermatozoa normal dan rerata motilitas spermatozoa abnormal.

Dari Tabel 2 dapat dilihat bahwa terdapat kecenderungan penurunan presentase motilitas normal spermatozoa tikus wistar (Rattus norvegicus) pada kelompok kontrol yang hanya diberikan paparan stres. Sedangkan pada kelompok perlakuan dan perlakuan 2 didapatkan peningkatan pada persentase motilitas normal spermatozoa tikus wistar (Rattus norvegicus).

Tabel 2. Hasil Perhitungan Rerata Motilitas Spermatozoa Tikus Wistar (Rattus norvegicus) setelah perlakuan stres dan pemberian kopi selama 50 hari.

\begin{tabular}{|c|c|c|}
\hline \multirow{2}{*}{$\begin{array}{l}\text { Kelompok } \\
\text { sampel }\end{array}$} & \multicolumn{2}{|c|}{ Motilitas Spermatozoa } \\
\hline & $\operatorname{Normal}(\%)$ & Abnormal $(\%)$ \\
\hline Kontrol (P0) & 18 & 82 \\
\hline $\begin{array}{l}\text { Perlakuan } \\
\text { (P1) }\end{array}$ & 66 & 34 \\
\hline $\begin{array}{l}\text { Perlakuan } \\
\text { (P2) }\end{array}$ & 52 & 48 \\
\hline
\end{tabular}

\section{Morfologi Spermatozoa}

Setelah dilakukan perlakuan pemberian paparan stres berupa cahaya dan kopi selama 50 hari maka didapatkan hasil morfologi spermatozoa tikus wistar (Rattus norvegicus) yang terbagi menjadi dua, yaitu morfologi normal dan abnormal

Tabel 3. Hasil Perhitungan Rerata Morfologi Spermatozoa Tikus Wistar (Rattus norvegicus) setelah perlakuan stres dan pemberian kopi selama 50 hari.

\begin{tabular}{lcc}
\hline \multirow{2}{*}{ Kelompok Sampel } & \multicolumn{2}{c}{$\begin{array}{c}\text { Morfologi } \\
\text { Spermatozoa }\end{array}$} \\
\cline { 2 - 3 } & $\begin{array}{c}\text { Normal } \\
(\boldsymbol{\%})\end{array}$ & $\begin{array}{c}\text { Abnormal } \\
(\boldsymbol{\%})\end{array}$ \\
\hline Kontrol (P0) & 74 & 26 \\
Perlakuan 1 (P1) & 77 & 23 \\
Perlakuan 2 (P2) & 79 & 21 \\
\hline
\end{tabular}

Dari Tabel 3 dapat dilihat bahwa terdapat kecenderungan penurunan presentase morfologi normal spermatozoa tikus wistar (Rattus norvegicus) pada kelompok kontrol yang hanya diberikan paparan stres. Sedangkan pada kelompok perlakuan dan perlakuan 2 didapatkan peningkatan pada presentase morfologi normal spermatozoa tikus wistar (Rattus norvegicus).

\section{Uji Komprabilitas Antar Kelompok}

Dari Tabel 4 didapatkan adanya perbedaan bermakna pada konsentrasi dan motilitas spermatozoa tikus wistar (Rattus 
Haris, Tendean, Turalaki: pengaruh pemberian kopi...

norvegicus) pada kelompok kontrol dan perlakuan yaitu $\mathrm{p}<0,05$. Sedangkan pada morfologi spermatozoa tikus wistar (Rattus norvegicus) pada kelompok kontrol dan perlakuan tidak didapatkan adanya perbedaan yang bermakna, yaitu $p>0,05$.

Tabel 4. Perbandingan Kualitas Spermatozoa Kelompok Kontrol Terhadap Kelompok Perlakuan 1:

\begin{tabular}{lccc}
\hline Kualitas Spermatozoa & KK & KP 1 & p \\
\hline Konsentrasi & 32.5 & 48 & 0,001 \\
Motilitas Normal & 18 & 66 & 0,003 \\
Morfologi Normal & 74 & 77 & 0,492 \\
\hline Ket: KK = Kelompok Kontrol, KP & $1=$ Kelompok \\
Perlakuan 1. & \multicolumn{4}{l}{}
\end{tabular}

Dari Tabel 5 didapatkan adanya perbedaan bermakna pada motilitas spermatozoa tikus wistar (Rattus norvegicus) antara kelompok kontrol dan perlakuan $2 \mathrm{p}<0,05$. Sedangkan pada motilitas dan morfologi spermatozoa tikus wistar (Rattus norvegicus) antar kelompok kontrol dan kelompok perlakuan 2 tidak didapatkan adanya perbedaan yang bermakna yaitu $\mathrm{p}>0,05$

Tabel 5. Perbandingan Kualitas Spermatozoa Kelompok Kontrol Terhadap Kelompok Perlakuan 2:

\begin{tabular}{lccc}
\hline $\begin{array}{l}\text { Kualitas } \\
\text { Spermatozoa }\end{array}$ & KK & KP 2 & p \\
\hline Konsentrasi & 32.5 & 14.4 & 0,869 \\
Motilitas Normal & 18 & 52 & 0,035 \\
Morfologi & 74 & 79 & 0,410 \\
Normal & & & \\
\hline $\begin{array}{l}\text { Ket: } \text { KK = Kelompok } \\
\text { Perlakuan 2 }\end{array}$ & & & \\
\end{tabular}

Dari Tabel 6 didapatkan adanya perbedaan bermakna pada konsentrasi spermatozoa tikus wista (Rattus norvegicus) antara kelompok perlakuan 1 dan perlakuan $2 \mathrm{p}<0,05$. Sedangkan pada motilitas dan morfologi spermatozoa tikus wsitar (Rattus norvegicus) kelompok perlakuan 1 dan perlakuan 2 tidak didapatkan adanya perbedaan yang bermakna $\mathrm{p}>0,05$.

Tabel 6. Perbandingan Kualitas Spermatozoa Kelompok Perlakuan 1 Terhadap Kelompok Perlakuan 2:

\begin{tabular}{lccc}
\hline $\begin{array}{l}\text { Kualitas } \\
\text { Spermatozoa }\end{array}$ & KP 1 & KP 2 & p \\
\hline Konsentrasi & 48 & 14.4 & 0,015 \\
Motilitas Normal & 66 & 52 & 0,128 \\
Morfologi Normal & 77 & 79 & 0,574 \\
\hline
\end{tabular}

Ket : KP $1=$ Kelompok Perlakuan 1, KP $2=$ Kelompok Perlakuan 2

\section{BAHASAN \\ Konsentrasi Spermatozoa}

Perbandingan konsentrasi antara kelompok kontrol (P0), kelompok perlakuan 1 (P1) dan kelompok perlakuan 2 (P2) didapatkan nilai rerata konsentrasi yang tinggi pada kelompok perlakuan 1 (P1), sedangkan pada kelompok perlakuan 2 (P2) didapatkan nilai konsentrasi yang rendah. Hal ini mungkin dapat disebabkan karena ekstrak kopi yang tidak homogen pada cairan sperma dan pelarut.

\section{Motilitas Spermatozoa}

Perbandingan motilitas antara kelompok kontrol (P0), kelompok perlakuan (P1) dan kelompok perlakuan 2 (P2) didapatkan nilai rerata motilitas yang tinggi pada kelompok perlakuan 1 (P1), sedangkan pada kelompok kontrol (P0) didapatkan nilai motilitas yang rendah. Tingginya nilai rerata motilitas kelompok perlakuan 1 (P1) dapat di sebabkan karena pemberian kopi. Pada kopi terdapat kafein, kafein meningkatkan produksi siklik adenosi monofosfat (cAMP) yang merangsang gerakan spermatozoa dalam sel dengan mengendalikan fosfodiesterase yang menganalisis enzim cAMP yang menggangu stimulasi proses fosforilasi tirosin pada kapasitasi spermatozoa dan langsung merangsang gerakan spermatozoa. $^{14}$

Sedangkan rendahnya nilai motilitas pada spermatozoa tikus kontrol dapat disebabkan karena pemberian stres dalam hal ini berupa cahaya menurut penelitian 
yang dilakukan oleh Mailman School of Public Health and Rutgers School of Public Health, Columbia University menyebutkan bahwa stres psikologis mempengaruhi konsentrasi, morfologi dan kemampuan sperma untuk membuahi sel telur. Pam Factor - Litvak, PhD dari associate professor of Epidemiology at the Mailman School of Public Health mengatakan pria yang merasa stres lebih sering memiliki konsentrasi sperma yang rendah pada saat ejakulasi dan mempunyai

\section{Morfologi Spermatozoa}

Perbandingan nilai rerata morfologi antara kelompok kontrol (P0), kelompok perlakuan $1(\mathrm{P} 1)$ dan kelompok perlakuan 2 (P2) didapatkan nilai rerata morfologi yang tinggi pada kelompok perlakuan 2 (P2), sedangkan pada kelompok kontrol didapatkan nilai morfologi yang rendah. Hal ini sesuai dengan penelitian sebelumnya yang dilakukan oleh Giblin et al menyebutkan bahwa stres mempunyai dampak negatif pada konsentrasi, motilitas dan mofologi spermatozoa. ${ }^{8}$ Cahaya merupakan inisiator pembentukan reactive oxygen species (ROS) yang dapat menyebabkan kerusakan sel, sehingga mengganggu kualitas spermatozoa. ${ }^{15,16}$

\section{Uji Komparabilitas Antar Kelompok}

Pada Tabel 4 yaitu perbandingan konsentrasi, motilitas dan morfologi antara kelompok kontrol (P0) dan kelompok perlakuan 1 (P1) didapatkan nilai perbandingan konsentrasi antara kelompok kontrol (P0) dan kelompok perlakuan 1 (P1) adalah p 0,001, nilai perbandingan motilitas kelompok kontrol (P0) dan kelompok perlakuan $1(\mathrm{P} 1)$ adalah p 0,003, dari data tersebut menunjukan adanya perbedaan yang signifikan yaitu $\mathrm{p}<0,05$. Sedangkan nilai perbandingan morfologi kelompok kontrol (PO) dan kelompok perlakuan 1 (P1) adalah p 0,492 yang menunjukan tidak adanya perbedaan yang signifikan $p>0,05$.

Tabel 5 yaitu perbandingan konsentrasi, motilitas dan morfologi antara kelompok kontrol (P0) dan perlakuan 2 (P2) didapatkan nilai perbandingan motilitas kelompok kontrol (P0) dan kelompok perlakuan 2 (P2) adalah p 0,035 yang menunjukan adanya perbedaan yang signifikan yaitu $p<0,05$. Sedangkan Nilai perbandingan konsentrasi antara kelompok kontrol (P0) dan perlakuan 2 (P2) adalah p 0,869 , nilai perbandingan morfologi kelompok kontrol (P0) dan perlakuan 2 (P2) adalah 0,410 dari data tersebut menunjukan tidak adanya perbedaan yang signifikan yaitu $\mathrm{p}<0,05$. Hal ini sesuai dengan penelitian yang dilakukan oleh Hasbi et al mendapatkan peningkatan motilitas spermatozoa. ${ }^{17}$

Tabel 6 yaitu perbandingan konsentrasi antara kelompok perlakuan 1 (P1) dan kelompok perlakuan 2 (P2) didapatkan nilai perbandingan konsentrasi kelompok kontrol (P0) dan kelompok perlakuan 2 (P2) adalah p 0,015 yang menunjukan adanya perbedaan yang signifikan yaitu $p<0,05$. Sedangkan Nilai perbandingan konsentrasi antara kelompok motilitas (P1) dan perlakuan 2 (P2) adalah p 0,128, dan nilai perbandingan morfologi kelompok kontrol (P1) dan perlakuan 2 (P2) adalah 0,574 dari data tersebut menunjukan tidak adanya perbedaan yang signifikan yaitu $p>0,05$. Hal itu disebabkan karena ekstrak kopi yang tidak homogen pada pencampuran dengan cairan sperma dan pelarut.

\section{SIMPULAN}

Pemberian kopi baik cairan kopi maupun ekstrak kopi pada tikus wistar (Rattus norvegicus) yang telah diberikan paparan stres berupa cahaya sebelumnya dapat menyebabkan peningkatan kualitas spermatozoa yang meliputi konsentrasi, motilitas dan morfologi.

\section{SARAN}

Disarankan untuk penelitian selanjutnya untuk menggunakan waktu yang lebih panjang.

Perlu dilakukan penelitian lebih lanjut untuk mengetahui manfaat kandungan lain yang terdapat di dalam biji kopi robusta. 
DAFTAR PUSTAKA

1. Aziz T. Cindo R. Fresca A. Pengaruh Pelarut Heksana dan Etanol, Volume, Pelarut dan Reaksi Terhadap Hasil Ekstraksi Minyak Kopi. Universitas Sriwijaya. Palembang ; 2009.

2. El-Gaafary, M.N., A.D. Daader, and A. Ziedan. Effects of caffein on bull semen quality and sperm penetration into cervical mucus. Anim. Reprod. Sci. 1990; 23;13-90.

3. Sobreiro BP, Lucon AM, Pasqualotto FF, Hallak J, Athayde KS, Arap S. Semen analysis in fertile patients undergoing vasectomy: reference values and variations according to age, length of sexual abstinence, seasonality, smoking habits and caffeine intake. Sao Paulo Med J 2005;123; $161-166$.

4. Parazzini F, Marchini M, Tozzi L, Mezzopane R, Fedele L. Risk factors for unexplained dyspermia in infertile men: a case-control study. Arch Androl 1993;31:105-113.

5. Ramlau-Hansen CH, Thulstrup AM, Bonde JP, et al. Semen quality according to prenatal coffee and present caffeine ex- posure: two decades of follow-up of a pregnancy cohort. Hum Reprod. 2008;23(12):2799-2805.

6. Talisman S. Cvitkovic P. Jurasovic J. Pizent A. Gavella M. Rocic B. Semen Quality and Reproductive Endocrine Function in Relation to Biomarkers of Lead, Cadmium, Zinc and Copper in Men. Environmental Health Perspectives.2000;108 [cited 2016 sept 13] avaible : http://www.ncbi.nlm.nih.gov/pmc/arti cles/PMC1637869/pdf/envhper00302 -0077.pdf

7. Mailman School of Public Health. Stress Degrades Sperm Quality. 2014 May 29 [ cited 2016 Sept 17] Avaible : https://www.mailman.columbia.edu/p ublic-health-now/news/stressdegrades-sperm-quality

8. Giblin PT. Poland ML. Moghissi KS et al. Effects of stress and characteristic adaptability on semen quality in helat men. Fertil Steril.1988;vol49;127-132

9. Turner, C.D \& J.T Bagnara. General Endocrinology. $6^{\text {th }}$ edition. W.B. Saunders. Philadelphia; 1976.

10.Wen-Pei, M., J. Cao, M. Tian, M. Cui, H. Han, Y. Yang, and L. Xu. Exposure to Chronic Constant Light Impairs Spatial Memory and Influences Longterm Depression in Rats, Neurosci. Res; 2007;59;224-230.

11.Welsh, D. K., J. S. Takahashi, and S. A. Kay. Suprachiasmatic Nucleus: Cell Autonomy and Network Properties (review). Annu. Rev. Physiol. 2010;72, 551-77.

12.Butler, M. P., L. J. Kriegsfeld, and R. Silver. Circadian regulation of endocrine functions, 473-505 dalam Pfaff, D.W., A.P. Arnold, A. M. Etgen, S. E. Fahrbach, R. T. Rubin, Eds, Hormones, Brain and Behavior, 2nd Ed., Academic Press. 2009

13.Macchi, M. and J. Bruce. Human Pineal Physiology and Functional Significance of Melatonin (review), Neuroendocrinology. 2004;25, 177195.

14. Narges N, Fatemeh T, Abdollhossein S. Effect of caffeine on motility and vitality of sperm and in vitro fertilization of outbreed mouse in T6 and M16 media. Iranian Journal of Reproductive Medicine. 2013;11(9):741-46.

15.Setiawan B. Suhartono E. Peroksidasi Lipid dan penyakit terkait stres oksidatif pada bayi premature. Maj Kedokt Indonesia.2007;vol57

16.Suarsana IN. Wresdiyati T. Suprayogi A. Respon stress oksidatif dan pemberian isoflavon terhadap aktivitas enzim superoksida dismutase dan peroksidasi lipid pada hati tikus. JITV. 2013;18;146-7

17.Hasbi. Sonjaya H. Gustina S. Pengaruh medium pemisah, penambah ektrak kopi sebelum proses pemisahan spermatozoa pembawa kromosom $\mathrm{x}$ dan $y$ dan lama penyimpanan terhadap kualitas semen cair kambing peranakan ettawa. JITP. 2011; vol1. 